\title{
Working Conditions and Career Aspirations of Waste Pickers in Lagos State
}

\author{
Isaac Jacob Omosimua *(D), Olurinola Isaiah Oluranti, Gershon Obindah (D) and Aderounmu Busayo \\ Department of Economics, Covenant University, Ota 112101, Nigeria; \\ olu.ogunrinola@covenantuniversity.edu.ng (O.I.O.); obindah.gershon@covenantuniversity.edu.ng (G.O.); \\ busayo.aderounmu@covenantuniversity.edu.ng (A.B.) \\ * Correspondence: jacob.isaac@stu.cu.edu.ng
}

check for updates

Citation: Omosimua, I.J.; Oluranti, O.I.; Obindah, G.; Busayo, A. Working Conditions and Career Aspirations of Waste Pickers in Lagos State. Recycling 2020, 6, 1. https:// doi.org/10.3390/recycling6010001

Received: 6 February 2020 Accepted: 16 September 2020 Published: 30 December 2020

Publisher's Note: MDPI stays neutral with regard to jurisdictional clai$\mathrm{ms}$ in published maps and institutional affiliations.

Copyright: (C) 2020 by the authors. Licensee MDPI, Basel, Switzerland. This article is an open access article distributed under the terms and conditions of the Creative Commons Attribution (CC BY) license (https:// creativecommons.org/licenses/by/ $4.0 /)$.

\begin{abstract}
In many cities of third world countries, managing waste represents a beehive of activities that involve human scavengers searching for reusable or recyclable items that are either consumed or sold to generate funds for personal and family upkeep, since alternative decent employment are not available for them in the formal employment sector. Many of these waste pickers are young, work without the necessary health and safety apparatus, and expose themselves to injury and various health hazards. Therefore, this study investigated the working conditions and career aspirations of waste pickers in Lagos State, Nigeria. Using the questionnaire approach, structured, semi-structured, and open-ended questions were asked, and the Statistical Package for Social Science (SPSS) was used to descriptively analyze the data collected and interpreted. The results showed that $87 \%$ of waste pickers in Lagos State have safety kits. In addition, the results showed flexibility in working hours and days since most waste pickers get to determine when and how they begin their work, i.e., $89 \%$ of the waste pickers spend 5 to 6 days a week in waste picking while $64 \%$ of them work between 10 and $14 \mathrm{~h}$ daily. Regarding earnings, the results showed that $68.3 \%$ of waste pickers earn between $\$ 2500$ (\$8.2) to $\$ 4900$ (\$16) daily. Finally, the results showed that despite access to safety kits, most waste pickers (54\%) had experienced one form or another of hazard which has affected their career aspiration. Therefore, based on the study results we recommend that the Lagos State and the Nigerian federal government should develop a system that ensures strict compliance to established rules or guidelines that ensures the safety and health of waste pickers on the job.
\end{abstract}

Keywords: working conditions; career aspirations; informal sector; waste pickers

\section{Introduction}

Some characteristics of developing nations are a backlog in waste collection coverage, open dumps, and unsanitary environments caused by improper disposal of waste [1,2]. This means that developing countries are faced with high tonnages of waste which affects human health, the environment, and safety directly.

Nigeria is the most populous country in Africa, home to over 200 million people which accounts for about $47 \%$ of the total population in West Africa [3]. Given the large population size of the Nigerian state, large tonnages of waste are generated daily [4]. Improper disposal of solid waste is an environmental challenge in Nigeria, and this challenge has resulted in blocked drainage systems and sewers, causing preventable flooding and painting a picture of an environmental catastrophe [5].

The activities of waste pickers involve recovering items such as metals, glass, polythene materials, plastic, irons, shopping bags, hospital drip bags, paper, cellular phones, wood, wire, batteries, and textiles, which are then offered for sale. Therefore, they are notable for reducing dumpsite waste to only organic waste which can be used as fertilizers and other materials not considered useful to them [6].

Waste pickers, among many others, transform domestic and industrial waste into wealth [7]. Their activities that reduce dumpsite waste to only organic waste, directly or 
indirectly help agencies responsible for waste management by reducing their costs. Waste pickers are very visible; in fact, they represent the most notable elements in the informal recycling scene which hinges around the following five major activities: waste separation, collection, transportation, processing of recyclables, and finally trading of the processed materials $[7,8]$. The recycling process begins with waste picking, an activity in which a large number of people, especially in developing countries, find great employment opportunity. Recycling in Nigeria is gradually gaining ground, making a notable contribution to poverty reduction and job creation [9].

It is widely known that waste pickers impact positively on the local economy of any country. However, these waste pickers are susceptible to injuries due to lack of the necessary personal protective equipment (PPE) and thus are faced with pitiable working conditions. The local and state government departments are not known for providing any form of support to waste pickers, and therefore they suffer from a wide range of illnesses, such as lead poisoning, skin diseases, respiratory infections, gastrointestinal diseases, and cuts from objects that are sharp [10]. Their health conditions are largely at risk because of the unsafe and hazardous means by which they carry out their activities. They are often found working where decaying organic wastes, including highly toxic medical waste, are deposited [11].

Despite the economic, environmental, and public health benefits which societies enjoy from waste picking activities, waste pickers are usually marginalized; and therefore their low earnings, degrading social status, negative experience with health and educational care, the career aspirations of waste pickers have not been the focus of many researchers [12]. With regard to the socio-economic conditions of waste pickers, there are conflicting results in the literature, as shown by the studies of $[6,9,13]$.

Some studies have examined the nature of informal recycling activities in Lagos State with a focus on health and economic implications [9,14]. Ref. [15,16] focused on the informal recycling sector in developing countries with an emphasis on organizing waste pickers to enhance their impact. Ref. [13,17] emphasized reduced waste and improved livelihood for all. However, remarkably, little is known about the working conditions and career aspirations of waste pickers in Lagos State, Nigeria. So, this study aims to fill this gap in the literature.

The main objective of this study is to investigate the working conditions and career aspirations of waste pickers in Lagos State, Nigeria. In a state where the unemployment rate is high, it is pertinent to investigate a researchable area that holds economic potential. This paper is organized as follows: Following the introduction, the theoretical framework and brief literature review are discussed, the methodology of the study is discussed in Section 3, the data, analysis, interpretation and conclusions are presented and discussed in Section 4. Finally, one area for future study is highlighted in Section 5.

\section{Theoretical Framework and Brief Survey of Literature}

\subsection{Theoretical Framework}

Much empirical work tends to support the human capital theory which was developed by Becker and Mincer about human capital investment and labour market earnings [12].

It explains both individuals' decisions to invest in human capital (education and training) and the pattern of individuals' lifetime earnings. Investments in education and training entail costs both in the form of direct expenses (like tuition) and foregone earnings during the investment period. Therefore, only those individuals who expect to be compensated by sufficiently higher lifetime earnings choose to invest. The human capital theory also explains the pattern of individuals' lifetime earnings. In general, the pattern of individuals' earnings is such that they start out low (when the individual is young) and increase with age, although earnings tend to fall somewhat as individuals near retirement. This pattern occurs because investment in skills acquisition improves earning stream over the lifetime. Going through a process repeatedly makes one a master of the process. Thus, rather than wait endlessly for formal jobs amidst high unemployment rates, young people 
do take up apprenticeships or informal jobs with a view to becoming a skilled craftsman in the trade selected.

$$
F C A=f(I H C, P L E)
$$

where PLE represents the pattern of individuals' lifetime earnings, IHC represents the investment in human capital, and FCA represents future career aspiration.

Equation (1) suggests that the future career aspiration of an individual depends on the pattern of the individual's lifetime earnings and investment in the individual's human capital.

In similitude with the human capital theory but more elaborate, the "self-concept theory (SCT)" by Donald Super argues that the future career aspiration of individuals changes over time with the acquisition of more experience, the pattern of an individual's lifetime earnings, gender, education, parental expectations, and parent's occupation and education level [18].

$$
F C A=f(P L E, E X P, G D, E D U, P E X, P O E)
$$

where FCA represents future career aspiration, PLE represents the pattern of individual's lifetime earnings, EXP represents experience, GD represents gender, EDU represents education, $P E X$ represents parental expectation, and $P O E$ represents parent's occupation and education level. SCT formed the theoretical foundation on which this study was built.

\subsection{Survey of Empirical Literature}

The activities of waste pickers are relevant to the growth of the economy as they help improve environmental quality and promote the health and wellbeing of people [5,6,9]. However, the health conditions of waste pickers are largely at risk because of the unsafe and extremely hazardous means by which they carry out their activities as they work under conditions of physical exertion for extended periods of time and hardly take time out to rest [11]. It is well documented that solid waste poses a serious risk to human health and the environment [19]. Economic inadequacies also push waste pickers to consume recovered food waste which can put them at risk of stomach infections, parasites infection, and food poisoning, which can cause nausea and diarrhoea [20]. The bioaerosols and other toxic compounds inhaled in the combustion process also portend danger to them. Burning waste and fuel exhaust fumes can cause eye irritation, lung infections, decreased lung functions, and different respiratory ailments [7,21].

The study by Nguyen et al. [22], in which 267 waste pickers were interviewed, reported spinal and lower extremity pain related to frequent kneeling which occurred in the process of collecting and sorting of solid waste, which posed as risks to their health and possible future career development. Findings from Mothiba [23] revealed that only $22 \%$ of the interviewed waste pickers viewed their health as poor and, when asked about their future career aspiration, $38 \%$ of the interviewed waste pickers intended to further their education, whereas the remaining $62 \%$ did not desire further education. The former intended to study nursing, handwork, teaching, and a majority wanted to obtain a Grade 12 certificate which could be obtained after successful completion of high school. The reasons given by those who were not interested in further education were many and varied. Some felt they were too old, others wanted to support their families, and the remainder thought some members of the community would make fun of them if they went back to school and sat in the same class with their children's age mates. Many of the responding waste pickers indicated that financial constraint was responsible for their early decision to drop out of school to make ends meet. A number of males, as well as females, reported that their peers laughed at them for being in the industry and that they were marginalized, whereas younger waste pickers said they feared public ridicule, and they were afraid to tell some of their friends about the kind of work they were involved in.

Ref. [12] studied the barriers that prevent street waste pickers from improving their socio-economic conditions. The survey research approach was used in their study, which 
took place between April 2011 and June 2012. The researchers conducted structured interviews with 914 persons involved in waste picking and a total of 69 off-takers in thirteen major cities spread across nine provinces in South Africa. The results of the study revealed that poor language proficiency, low levels of schooling, limited language skills, low and uncertain level of income, as well as poor access to basic and social needs, hindered waste pickers from improving on their socio-economic conditions. The study recommended the implementation of intervention policies aimed at improving the socio-economic wellbeing of waste pickers.

Ref. [24] assessed the perception of households on solid waste recycling and the benefits accruing to households in Kaduna state, Nigeria. The approach used in the study was quantitative. Respondents were selected using stratified random sampling, and 500 questionnaires were administered to the households. The study used descriptive statistics to analyze the benefit of and perception of waste recycling. The result of the study showed that households with low income recycled their waste more and earned income benefits as compared with those with higher income. The study also showed that higher-income household's perception of waste pickers was degrading.

Ref. [6] studied the social, economic, health, and environmental implications of solid waste scavenging activity in Olusosun, one of the government's designated open waste dumpsites in Lagos, Nigeria. The study utilized primary data obtained from waste pickers and simple techniques such as mean, frequency distributions, percentages, and crosstabulations among various variables were used in the analysis and interpretation of the data collected. The results showed that scavengers reduce the waste on the site to almost only organic materials since other materials such as metals, plastic, glass and polythene materials are recovered for reuse or sale. This reduces the quantity and leaves only organic materials to be buried. In addition, scavengers have helped agencies responsible for waste management in reducing financial and technological commitments. The study concluded that scavenging should be regulated to make sure that operations become environment friendly, thus, creating fewer hazards to both the operators and members of the public.

Ref. [25] studied the role of the informal sector in sustainable municipal solid waste management using Lagos State, Nigeria, as a case study. The researchers examined how informal sector players contribute to waste management, waste recycling, and wasteto-wealth activities in Lagos State, Nigeria. The study was based on the data collected from field observations, interviews, and questionnaires administered to waste collectors, scavengers, waste cart pushers, resource merchants, recyclers, and other stockholders of the informal municipal solid waste management in sixteen local government areas (LGAs) of Lagos State, Nigeria. The results of the study showed that the search for valuables, recyclables, and reusable items at dumpsites has always been driven by poverty and a desire to earn a living. The study concluded that the actors of the informal sector in municipal waste management had been working under conditions that put their health, which was an important asset to them, at risk for not undertaking safety preventions. The study established that there was a ready and profitable market for reusable and recyclable municipal waste materials in Lagos State, Nigeria.

Some studies have proposed that protective gear such as clothing, gloves, and boots should be given to waste pickers to reduce pathogenic infections and increase their activities $[8,16,26]$, however, a lot of controversy has been stirred. It was experienced in Calcutta, India that the waste pickers sold the personal protective equipment (PPE) given to them and preferred to work unguardedly [27]. Thus, due to the informal and undefined nature of waste picking, their working conditions are somewhat difficult to improve on. Some studies are of the opinion that employment opportunities and decent earnings abound in waste picking activities [6,9,13]; others have questioned the decency of waste picking [12]. This study was carried out to provide more insight and reduce this controversy by investigating the socio-economic conditions and career aspirations of waste pickers in Lagos State, Nigeria. 


\section{Methodology}

\section{Research Design and Instrument of Data Collection}

Lagos is a state in Nigeria, located in the southwestern part of the country $\left(6^{\circ} 35^{\prime} \mathrm{N}\right.$, $3^{\circ} 45^{\prime} \mathrm{E}$ ). It is the smallest state in terms of area of land, with about $3577 \mathrm{Km}^{2}$ of which $22 \%$ are lagoons and creeks. In the north and east, it is bounded by Ogun State, in the west by the Republic of Benin, and in the south by the Atlantic Ocean [28]. According to Wale [5], with per capita waste generation of $0.5 \mathrm{~kg}$ per day, Lagos State generates more than 10,000 tons of urban waste every day. The 2020 population of Lagos State which is the most populous state in Nigeria is 22 million, and with a growth rate of $3.26 \%$, the quantity of solid waste generated in the state should keep increasing "ceteris paribus" [4]. Given that some of the key determinants of the quantity of waste generated are population size and developmental state, Lagos State has the highest quantity of pickable waste to deal with in Nigeria [4,29].

Solid waste management in Lagos State entails the collection of waste from points of generation to open dumps. There are six active dumps in Lagos as follows: Ojota dump (Olusosun), Okofili (Souls 2), Souls 3, Katangowa (Abule Egba), and Ewu elepe Epe. The Ojota dump, as well as the Okofili and Katangowa dumpsites (which are the dumpsites covered in this study), are the most frequently used [30]. These open dumps are open to waste pickers to scavenge for recyclable and reusable items, an activity that, over time, has served as a means of livelihood to them. This information informed the choice of Lagos State as the case study for this study.

According to Nzeadibe \& Iwuoha [9], there are over 1000 waste pickers in Lagos State. This study randomly selected 127 waste pickers made up of 26 females and 101 males and administered questionnaires aimed at investigating their working conditions and career aspirations. The self-concept theory was used as a guide for the questions asked. The research instrument used was the survey approach using a questionnaire containing structured and semi-structured questions. The questionnaire was categorized into four sections. Section A was concerned with general questions relating to their earnings, job details, working days and hours, hazards experienced, and preventive measures. Section B enquired about their future career aspirations. Section $C$ concentrated on the biodata of respondents, and the last section asked about their relationship with local government authorities. The primary tools of analysis for this study were basic descriptive statistical analyses. For the statistical analysis, simple techniques such as mean, frequency distributions, percentages and cross-tabulations between various variables were carried out through the use of the Statistical Package for Social Science (SPSS).

\section{Analysis of Data}

\subsection{Data Presentation and Analysis}

For this study, one hundred and twenty-seven waste pickers were randomly selected; $86.4 \%$ of the total population of respondents constituting 13 females and 95 males who were self-employed, $12.8 \%$ of the respondents constituting 12 females and 4 males who were employed waste pickers, and $0.8 \%$ of the respondents were represented by one apprentice. It is imperative to note that of the total respondents, 26 were found to be female workers, whereas 101 were male workers. The large percentage of male waste pickers over female workers could be as a result of the demands of the job which females find inconvenient and stressful [31,32]. A breakdown of their responses are summarized in themes and presented below.

\subsubsection{Safety and Wellbeing of Waste Pickers in Lagos State}

Commitment to safety has a direct relationship with job performance and job satisfaction $[33,34]$. The activities of waste pickers are important to the economy; as such, their safety is equally important [15]. With respect to the question on safety, Figure 1 \& Table 1 revealed that 104 waste pickers representing about $87 \%$ of the total study population had access to safety kits and used them on the job, whereas 15 waste pickers representing about 
$13 \%$ of the study respondents did not (provided in Appendix A is an extended detail of Figure 1). It is pertinent to note that ensuring safety can induce efficiency and reduce the risk of injury or accidents on the job.

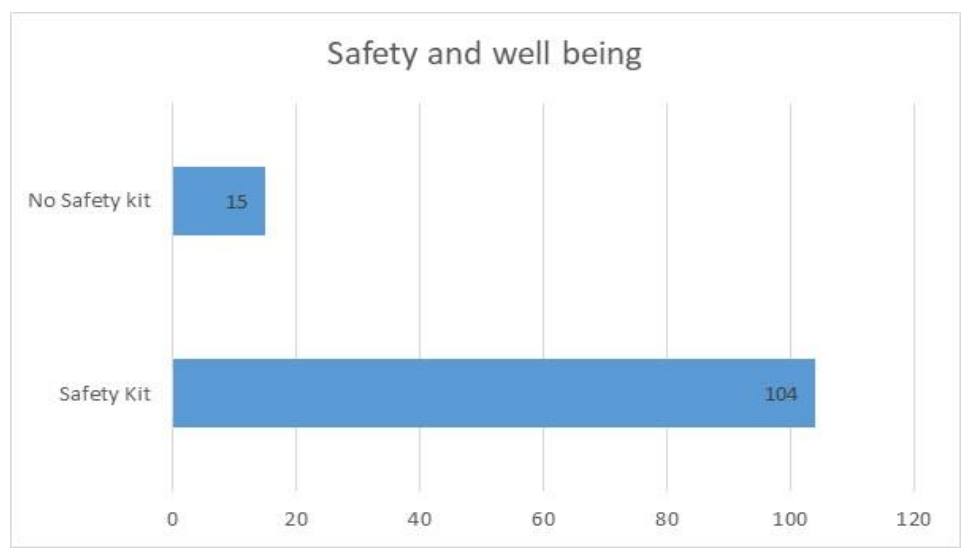

Figure 1. Safety and wellbeing of waste pickers. Source: Computed by authors.

Table 1. Safety and wellbeing of waste pickers.

\begin{tabular}{ccccc}
\hline \multicolumn{5}{c}{ Safety and Well-Being } \\
& Male & Female & Total & \% \\
\hline Safety Kit & 90 & 14 & 104 & 87.394958 \\
\hline No Safety kit & 3 & 12 & 15 & 12.605042 \\
\hline Total & 93 & 26 & 119 & 100 \\
\hline
\end{tabular}

\subsubsection{Hazards Experienced during Waste Picking}

Figure 2 shows the kinds of hazards that workers have experienced since they started picking waste. Out of the 124 persons who responded to this question, 67 waste pickers representing $54 \%$ of the study respondents are reported to have experienced one form of hazard or the other and 56 workers representing about $45.2 \%$ responded to have never experienced any hazards since they began waste picking. There was only one person who was indifferent in their response (provided in Appendix A and Table 2 is an extended detail of Figure 2).

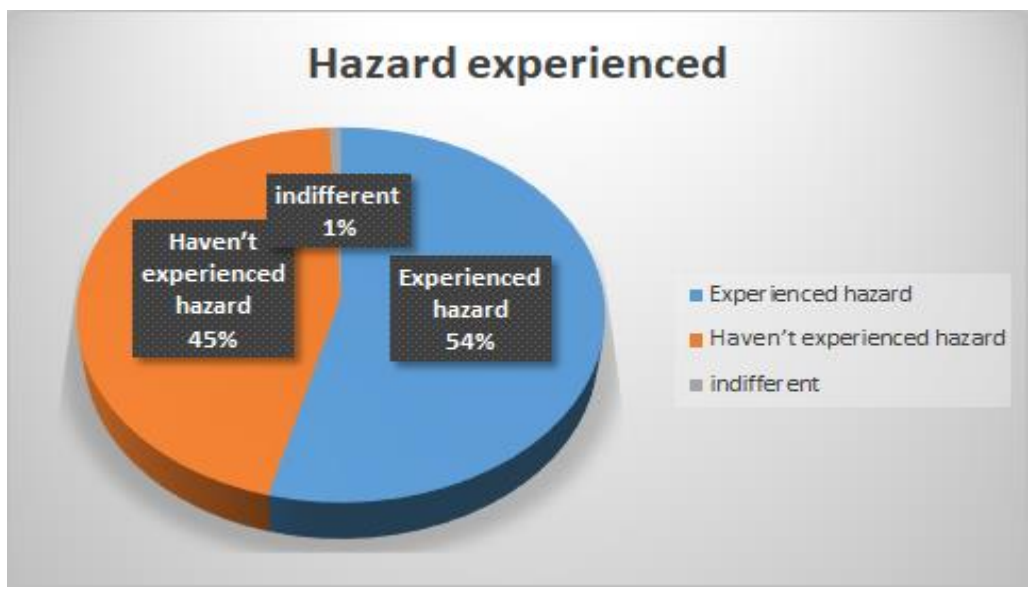

Figure 2. Hazards experienced during waste picking. Source: Computed by authors. 
Table 2. Hazards experienced during waste picking.

\begin{tabular}{ccccc}
\hline \multicolumn{5}{c}{ Hazard Experienced } \\
\\
\hline Male & Female & Total & \% \\
\hline Experienced hazard & 47 & 20 & 67 & 54.032258 \\
\hline Haven't experienced hazard & 51 & 5 & 56 & 45.16129 \\
\hline indifferent & 0 & 1 & 1 & 0.8064516 \\
\hline Total & 98 & 26 & 124 & 100 \\
\hline
\end{tabular}

4.1.3. Number of Working Days of Waste Pickers in Lagos State, Nigeria

From Figure 3, three workers spend 3-4 days per week on waste picking, 108 workers representing about $89 \%$ of the study population spend 5-6 days a week on waste picking, and 10 workers work all the days of the week representing about $8.3 \%$ of the study population (provided in Appendix A and Table 3 is an extended detail of Figure 3). This shows flexibility in the working days, as workers could choose the number of days they want to work, depending on their needs.

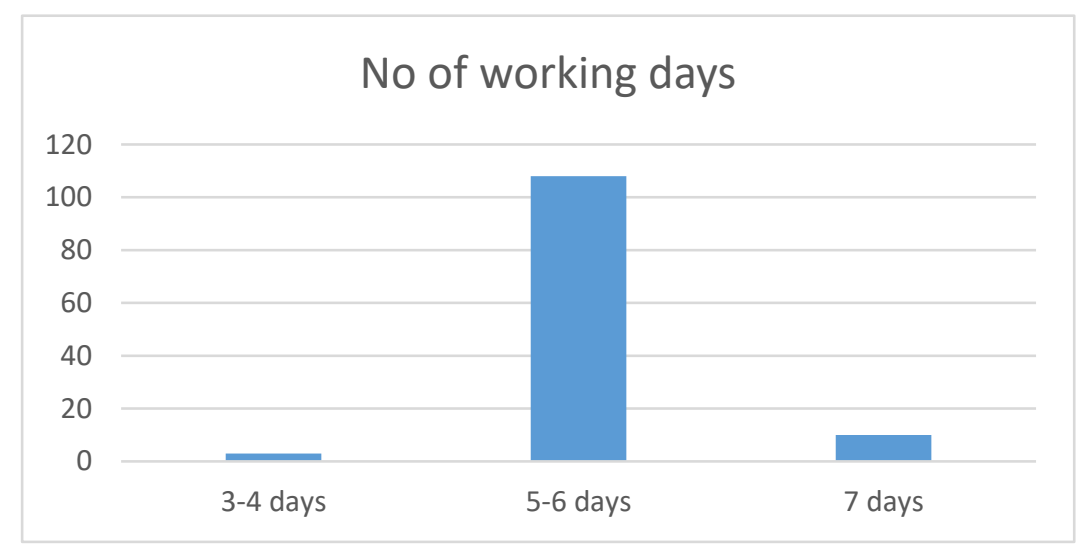

Figure 3. Number of working days of waste pickers in Lagos State. Source: Computed by authors.

Table 3. Number of Working Hours of Waste Pickers in Lagos State, Nigeria.

\begin{tabular}{ccccc}
\hline \multicolumn{5}{c}{ Number of Working Days } \\
\hline & Male & Female & Total & \% \\
\hline 3-4 days & 2 & 1 & 3 & 2.4793388 \\
\hline 5-6 days & 86 & 22 & 108 & 89.256198 \\
\hline 7 days & 8 & 2 & 10 & 8.2644628 \\
\hline Total & 96 & 25 & 121 & 100 \\
\hline
\end{tabular}

4.1.4. Number of Working Hours of Waste Pickers in Lagos State, Nigeria

Figure 4 and Table 4 show that five waste pickers representing $4 \%$ of the study population work between 5 to $8 \mathrm{~h}$ daily. Forty workers representing 32\% of the respondents work 8 to $10 \mathrm{~h}$ daily. Eighty waste pickers, representing $64 \%$ of the study population, work between 10 to $14 \mathrm{~h}$ daily (provided in Appendix A is an extended detail of Figure 4). This shows flexibility in the working hours of waste pickers. 


\title{
NO OF WORKING HOURS
}

\author{
- 5-8 hours \\ 8 -10 hours \\ 10-14 hours
}

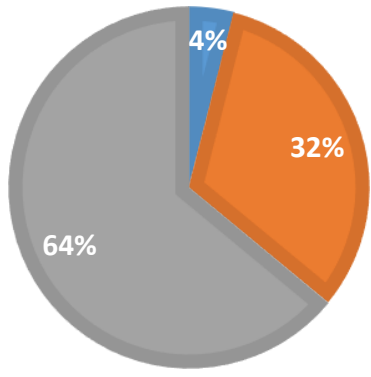

Figure 4. Working hours of waste pickers in Lagos, Nigeria. Source: Computed by authors.

Table 4. Working hours of waste pickers in Lagos, Nigeria.

\begin{tabular}{ccccc}
\hline \multicolumn{5}{c}{ Number of Working Hours } \\
\hline & Male & Female & Total & \% \\
\hline $5-8 \mathrm{~h}$ & 2 & 3 & 5 & 4 \\
\hline $8-10 \mathrm{~h}$ & 25 & 15 & 40 & 32 \\
\hline $10-14 \mathrm{~h}$ & 73 & 7 & 80 & 64 \\
\hline Total & 100 & 25 & 125 & 100 \\
\hline
\end{tabular}

\subsubsection{Earnings of Waste Pickers in Lagos State, Nigeria}

Motivation has a direct impact on work performance [35]. Motivation can both be internal and external and can initiate work-related behaviour [36]. Motivation can come in the form of earnings. In this study, and as shown in Figure 5, about 68.3\% (82 waste pickers) of the respondents earn between $\mathrm{N} 2500$ (\$8.2) to $\$ 4900$ (\$16), whereas about 31.7\% (38 waste pickers) of the respondents earn below $\mathrm{N} 2500$ (\$8.2) (provided in Appendix A and Table 5 is an extended detail of Figure 5).

\section{Earnings of waste pickers per day}

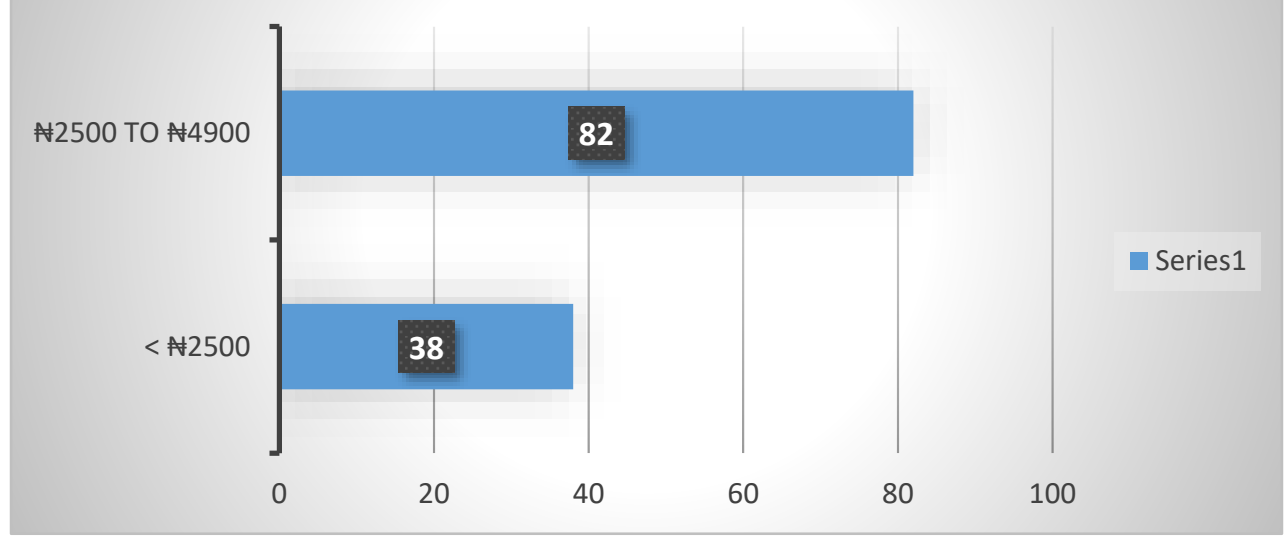

Figure 5. Earnings of waste pickers in Lagos State, Nigeria. Source: Computed by authors. 
Table 5. Earnings of waste pickers in Lagos State, Nigeria.

\begin{tabular}{|c|c|c|c|c|}
\hline \multicolumn{5}{|c|}{ Earnings per Day } \\
\hline & Male & Female & Total & $\%$ \\
\hline$<£ 2500$ & 20 & 18 & 38 & 31.666667 \\
\hline $\mathrm{N} 2500$ to $\mathrm{N} 4900$ & 81 & 1 & 82 & 68.333333 \\
\hline Total & 101 & 19 & 120 & 100 \\
\hline
\end{tabular}

\subsubsection{Future Career Aspiration of Waste Pickers in Lagos State, Nigeria}

Figure 6 and Table 6 show that out of the 124 respondents, 69 waste pickers representing $55.6 \%$ want to venture into their dream businesses in the future, 47 workers (representing about $38 \%$ ) desire to remain self-employed in the future, one worker (representing $0.80 \%$ ) intends to secure a formal sector job in the future, five workers (representing $4 \%$ ) are working to obtain funds to further their education, and two waste pickers (representing 1.6\%) had other reasons outside our structured questions (provided in Appendix A is an extended detail of Figure 6).

\section{Future career aspiration of waste pickers}

To venture into other dream businesses

To remain self-employed

Furtherance of formal education

other reasons

To secure desired formal job
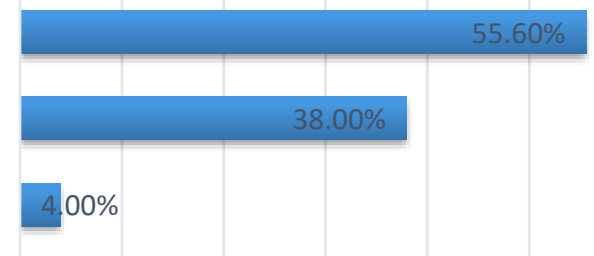

$1.60 \%$

$0.80 \%$

0.00\% 10.00\% 20.00\% 30.00\% 40.00\% 50.00\% 60.00\%

Figure 6. Future career aspiration of waste pickers in Lagos State, Nigeria. Source: Computed by authors.

Table 6. Future career aspiration of waste pickers in Lagos State, Nigeria.

\begin{tabular}{cccccc}
\hline \multicolumn{5}{c}{ Future Career Aspiration } & \\
\hline & Male & Female & Total & $\%$ \\
\hline To secure desired formal job & 1 & 0 & 1 & 0.8064516 \\
\hline other reasons & 2 & 0 & 2 & 1.6129032 \\
\hline Furtherance of formal education & 5 & 0 & 5 & 4.0322581 \\
\hline To remain self-employed & 41 & 6 & 47 & 37.903226 \\
\hline To venture into other dream businesses & 50 & 19 & 69 & 55.645161 \\
\hline Total & 99 & 25 & 124 & 100 \\
\hline
\end{tabular}

\subsection{Discussion}

Themes from Sections 4.1.1-4.1.5 aided the investigation of the working condition of waste pickers in Lagos State. Firstly, for safety and wellbeing, most of the waste pickers have access to basic safety kits which are boots and gloves. However, the frequency of changing these kits is low, and as a result, they become susceptible to the harm associated with working in open dumps. Protective footwears need to be worn more often by waste 
pickers to avert the risk of foot injuries on the dumpsite. According to Danish et al. [37], controlling hazardous situations creates an efficient and competent environment.

Secondly, most waste pickers have suffered from one hazard or the other despite having access to safety kits. This is perhaps due to the nature of their working environment, which is rough and unhealthy. Increased hazards can affect job performance, and its control creates an efficient and competent environment. Therefore, it is important to control hazardous situations.

Thirdly, most waste pickers spend three to four days a week waste picking, perhaps due to the laborious nature of the job. It is also revealed in this study that most waste pickers work between 10 and $14 \mathrm{~h}$ daily. In waste picking or scavenging, the more you pick reusable waste, the more money you earn. However, it is important to know your strength limit to avoid health-related incidences.

Fourthly, most of the waste pickers in Lagos earn between $\$ 2500$ (\$8.2) and $\$ 4900$ (\$16). A minority of the waste pickers (respondents) earn below $\$ 2500$ (\$8.2) daily. Interestingly, this study revealed that if waste pickers work only five days in a week, then $68.3 \%$ of the waste pickers would earn at least $\$ 12,500$ (\$40.8) per week, $\$ 50,000$ (\$163.2) monthly, and $\mathrm{N} 600,000$ (\$1958) annually. This conforms with the works of $[6,9,13]$ which insinuated that the income of waste pickers is not really low. The monthly income of the majority of waste pickers is above the country's $\$ 18,000$ (\$58.7) per month minimum wage and about $\$ 560,000$ (\$1827.4), the annual per capita income (PCI) (WDI, 2018). This means the government needs to create more awareness about waste picking and change the stereotype of this job as being a job for the poor. This would educate citizens about the profitability and viability of this work, while also adding value to the environment.

Finally, for the career aspirations of waste pickers in Lagos State, a good number of them are enjoying the fact that they are self-employed and wish to become processors in the future. However, most of them would love to venture into their dream businesses in the future, and perhaps due to the laborious nature of waste picking, they do not see any future in it. A few of these waste pickers want to go back to school.

\subsection{Findings, Conclusions and Recommendations}

Firstly, the results of this study show that most (87\%) waste pickers in Lagos State have safety kits, especially boots and gloves. Secondly, the result shows flexibility in the working hours and days as most of them get to determine when and how they get to begin their work, i.e., $89 \%$ of the waste pickers spend 5 to 6 days a week in waste picking while $64 \%$ of them work between 10 to $14 \mathrm{~h}$ daily. Thirdly, the study found that $68.3 \%$ (representing the most) of waste pickers earn between $\$ 2500$ (\$8.2) to $\$ 4900$ (\$16) daily. Fourthly, despite access to safety kits and flexibility in working hours and days, the result of the study shows that most waste pickers $(54 \%)$ have experienced one form of hazard or the other and this has affected the career aspiration of these waste pickers. While a good number $(38 \%)$ of them are enjoying the fact that they are self-employed and wish to continue in their line of business, most of them would love to venture into other businesses in the future, perhaps due to the nature of waste picking. A small number of these waste pickers $(4 \%)$ are sourcing funds to go back to school.

In conclusion, waste picking is the act of picking reusable or recyclable waste items originally considered to be useless. Waste pickers are key agents in the transformation of domestic and industrial waste; as such, they are the most noticeable in the recycling scene in Lagos State. Waste picking has impacted positively on the local economy of Lagos State by contributing to the cleanliness of the environment and creating jobs for the vulnerable. However, our investigation into the working conditions and career aspirations of these waste pickers shows that they are susceptible to a wide range of illnesses because of the unsafe nature of carrying out their activities. They are often found working where decaying organic wastes, including highly toxic medical wastes, are deposited, and therefore most of these waste pickers wish to change their career path in the future. 
Waste picking has the potential of creating an avenue for workers to achieve their goals and aspirations which could create a sense of fulfilment on the part of these workers. Therefore, given the economic relevance of waste pickers, this study recommends that Lagos State and the Nigerian government should develop a system that ensures strict compliance to established rules and guidelines that ensure the safety of the health of waste pickers on the job, guidelines such as the provision of healthcare incentives and routine health checks for waste pickers, as well as strict compliance with respect to using personal protective gear on the job and staying off-site during rainfall and harsh weather conditions to protect waste pickers from gaseous emissions such as methane.

\section{Area for Future Study: The Blue Box Initiative}

An increase in population has a positive relationship with waste generated; thus, it is expected that the activities of both street and dumpsite waste pickers should intensify in the future. However, to protect the environment, which according to ref. [38] consists of the soil, water, air, and a host of medicinal products and food, efficient waste management practices need to be taken into account. To this effect, the Lagos State Waste Management Agency (LAWMA), initiated the blue box Initiative in 2020. The blue box initiative is a single stream recyclable collection program that encourages the separation of recyclable materials from the point of generation. The aims of the initiative include capturing about $50 \%$ recyclables upstream, attracting investors and creating green jobs, reducing the carbon footprint, and promoting a healthier and cleaner environment.

The initiative aims to achieve zero tolerance of scavenging (waste picking) in both streets and dumpsites by June 2021, which would impact the means of livelihood of waste pickers. What will be the impact of this initiative on the livelihoods of waste pickers? This is a relevant question for future research.

Author Contributions: I.J.O. (Corresponding Author) conceptualized the study and is the main brain behind the research work. O.I.O. and G.O. provided technical support, reviewed and edited the work. A.B. carried out the data analysis. All authors have read and agreed to the published version of the manuscript.

Funding: This research was funded by the Covenant University Centre for Research Innovation and Discovery (CUCRID).

Data Availability Statement: Not applicable.

Acknowledgments: The authors of this research work acknowledge the publication support from Covenant University Centre for Research Innovation and Discovery (CUCRID).

Conflicts of Interest: The authors declare no conflict of interest.

$\begin{array}{ll}\text { Abbreviations } \\ \mathrm{F} & \text { female } \\ \mathrm{M} & \text { male } \\ \mathrm{T} & \text { total } \\ \mathrm{TPR} & \text { Total Population of Respondents }\end{array}$




\section{Appendix A}

\begin{tabular}{|c|c|c|c|c|c|c|}
\hline & Description & $\mathbf{F}$ & $\mathbf{M}$ & $\mathbf{T}$ & TPR & $\%$ \\
\hline 1a. & Waste pickers who are self employed & 13 & 95 & 108 & 125 & 86.4 \\
\hline b. & Waste pickers with safety kits & 11 & 90 & 101 & 108 & 93.5 \\
\hline c. & Waste pickers without safety kits & 1 & 1 & 2 & 108 & 1.85 \\
\hline 2a. & Employed Waste Pickers & 12 & 4 & 16 & 125 & 12.8 \\
\hline b. & Access to safety kits & 0 & 3 & 3 & 16 & 18.8 \\
\hline c. & No access to safety kits & 11 & 2 & 13 & 16 & 81.3 \\
\hline d. & Remuneration by kg of recovered waste & 12 & 2 & 14 & 16 & 87.5 \\
\hline e. & Remuneration by other means & 0 & 1 & 1 & 16 & 6.25 \\
\hline 3 & Apprentice & 0 & 1 & 1 & 125 & 0.8 \\
\hline $4 \mathrm{a}$ & Waste pickers who step on dangerous objects & 20 & 47 & 67 & 124 & 54 \\
\hline b. & Waste pickers who haven't experienced any hazard & 5 & 51 & 56 & 124 & 45.2 \\
\hline c. & Indifferent respondent(s) & 1 & 0 & 1 & 124 & 0.81 \\
\hline $5 a$ & Infection prevention measures by WP: local herbs & 24 & 99 & 123 & 125 & 98.4 \\
\hline b. & Infection prevention measures by WP: antibiotics on prescription & 2 & 0 & 2 & 125 & 1.6 \\
\hline $6 a$. & No of days per week spent on waste picking: 3-4 days & 1 & 2 & 3 & 121 & 2.48 \\
\hline b. & No of days per week spent on waste picking: 5-6 days & 22 & 86 & 108 & 121 & 89.3 \\
\hline c. & No of days per week spent on waste picking: 7 days & 2 & 8 & 10 & 121 & 8.26 \\
\hline $7 a$. & No of work hours: 5 to $8 \mathrm{~h}$ & 3 & 2 & 5 & 125 & 4 \\
\hline b. & No of work hours: 8 to $10 \mathrm{~h}$ & 15 & 25 & 40 & 125 & 32 \\
\hline c. & No of work hours: 10 to $14 \mathrm{~h}$ & 7 & 73 & 80 & 125 & 64 \\
\hline $8 a$. & Earnings from waste picking per day $<\$ 2500$ & 18 & 20 & 38 & 120 & 31.7 \\
\hline b. & Earnings from waste picking per day $\$ 2500$ to $\$ 4900$ & 1 & 81 & 82 & 120 & 68.3 \\
\hline 9a. & Why waste picking?: Preference for self-employment & 6 & 41 & 47 & 124 & 37.9 \\
\hline b. & Why waste picking?: Inability to secure desired formal employment & 0 & 1 & 1 & 124 & 0.81 \\
\hline c. & Why waste picking?: To raise funds for my education. & 0 & 5 & 5 & 124 & 4.03 \\
\hline d. & Why waste picking?: To raise funds for my dream business. & 19 & 50 & 69 & 124 & 55.6 \\
\hline
\end{tabular}

\section{References}

1. Oteng-Ababio, M. Rethinking waste as a resource: Insights from a low-income community in Accra, Ghana. City Territ. Archit. 2014, 1, 10. [CrossRef]

2. Yavini, T.D.; Musa, A.A. Municipal solid waste and pollution management in Jalingo metropolis: Problems, challenges and strategies. J. Environ. 2013, 2, 125-133.

3. Against My Will State of World Population; United Nations Population U.S., 2019.

4. Dlamini, S.; Simatele, M.D.; Kubanza, N.S. Municipal solid waste management in South Africa: From waste to energy recovery through waste-to-energy technologies in Johannesburg. Local Environ. 2019, 24, 249-257. [CrossRef]

5. Wale, B. Solid waste management in Nigeria. BioEnergy Consult. 2019. Available online: https://www.bioenergyconsult.com/ solid-waste-nigeria / (accessed on 6 February 2020).

6. Afon, A. A survey of operational characteristics, socio-economic and health effects of scavenging activity in Lagos, Nigeria. Waste Manag. Res. 2012, 30, 664-671. [CrossRef] [PubMed]

7. Ray, M.R.; Mukherjee, G.; Roychowdhury, S.; Lahiri, T. Respiratory and general health impairments of rag pickers in India: A study in Delhi. Int. Arch. Occup. Environ. Health 2004, 77, 595-598. [CrossRef] [PubMed]

8. Ojeda-Benitez, S.; Armijo-de-Vega, C.; Ramirez-Bareto, M.E. Formal and informal recovery of recyclables in Mexicali, Mexico: Handling alternatives. Resour. Conserv. Recycl. 2002, 34, 273-288. [CrossRef]

9. Nzeadibe, T.C.; Iwuoha, H.C. Informal Waste Recycling in Lagos; IWM Business Services Ltd.: Nigeria, Africa, 2008; Volume 9, pp. 24-31. 
10. Cointreau-Levine, S. Guidance Pack: Private Sector Participation in Municipal Solid Waste Management. In 2. Guidance Note: A Review of Recent International Experience of Private Sector Involvement in Munnicipal Solid Waste Management and Guidelines for the Steps to be Taken to Ensure Successful Private Sector Perticipation in the Coming Years; Skat: Sakskobing, Denmark, 2000.

11. Awopetu, M.S.; Awopetu, R.G.; Sample, E.D.; Olufiropo, A.O.C.; Awokola, S.; Fullen, M.A.; Hammond, F.N. Municipal solid waste management and the role of waste-pickers in Nigeria. Int. J. Educ. Res. 2014, 2, 1-12.

12. Viljoen, K.; Blaauw, P.; Schenck, R. I would rather have a decent job: Potential barriers preventing street-waste pickers from improving their socio-economic conditions. S. Afr. J. Econ. Manag. Sci. 2016, 19, 175-191. [CrossRef]

13. Binion, E.; Gutberlet, J. The effects of handling solid waste on the wellbeing of informal and organized recyclers: A review of the literature. Int. J. Occup. Environ. Health 2012, 18, 43-52. [CrossRef]

14. Ogunrinola, I.O.; Adepegba, E.O. Health and economic implications of waste dumpsites in cities: The case of Lagos, Nigeria. Int. J. Econ. Finance 2012, 4, 239-251. [CrossRef]

15. Medina, M. The Informal Recycling Sector in Developing Countries: Organizing Waste Pickers to Enhance Their Impact; World Bank: Washington, DC, USA, 2008.

16. Wilson, D.C.; Velis, C.; Cheeseman, C. Role of informal sector recycling in waste management in developing countries. Habitat Int. 2006, 30, 797-808. [CrossRef]

17. Oates, L.; Sudmant, A.; Gouldson, A.; Gillard, R. Reduced Waste and Improved Livelihoods for All: Lessons on Waste Management from Ahmedabad, India; White Rose: Plymouth, UK, 2018.

18. Al-Bahrani, M.A.; Allawati, S.M.; Abu Shindi, Y.A.; Bakkar, B.S. Career aspiration and related contextual variables. Int. J. Adolesc. Youth 2020, 25, 703-711. [CrossRef]

19. Medina, M. Serving the unserved: Informal refuse collection in Mexican cities. Waste Manag. 2005, 23, 390-397. [CrossRef] [PubMed]

20. Da Silva, M.C.; Fassa, A.G.; Siqueira, C.E.; Kriebel, D. Word at work: Brazilian rag pickers. Occup. Environ. Med. 2005, 62, 736-740. [CrossRef]

21. Gomez-Correa, J.; Agudelo-Suarez, A.; Ronda-Perez, E. Social conditions and health profile of recyclers from Mendellin. Rev. Salud Públ. 2008, 10, 706-715.

22. Nguyen, H.; Chalin, C.; Lam, T.; Maclaren, V. Health and Social Needs of Waste Pickers in Vietnam; WASTE-ECON: South East Asia, 2003.

23. Mothiba, M.P. A Study on Working Conditions and Health Status of Waste Pickers Working at Landfill Sites in the City of Tshwane Metropolitan Municipality. Ph.D. Thesis, University of South Africa, Pretoria, South Africa, May 2016.

24. Abd'Razack, N.T.; Medayese, S.O.; Shaibu, S.I.; Adeleye, B.M. Habits and benefits of recycling solid waste among households in Kaduna, North West Nigeria. Sustain. Cities Soc. 2017, 28, 297-306. [CrossRef]

25. Ogbonna, A.C.; Mikailu, A. The role of the informal sector in sustainable municipal solid waste management: A case study of Lagos State, Nigeria. Ann. Fac. Eng. Hunedoara 2019, 17, 117-122.

26. Hina, Z.; Devadas, V. Urban solid waste management in Kanpur: Opportunities and perspectives. Habitat Int. 2008, $32,58-73$.

27. International Source Book on Environmentally Sound Technologies for Municipal Solid Waste Management; United Nations Environmental Programme (UNEP): Nairobi, Kenya, 1996.

28. Salami, H.A.; Adegite, J.O.; Bademosi, T.T.; Lawal, S.O.; Olutayo, O.O.; Olowosokedile, O. A review on the current status of municipal solid waste management in nigeria: Problems and solutions. J. Eng. Res. Rep. 2018, 3, 1-16. [CrossRef]

29. Kaza, S.; Yao, L.; Bhada-Tata, P.; van Woerden, F. What a Waste 2.0: A Global Snapshot of Solid Waste Management to 2050; The World Bank: Washington, DC, USA, 2018.

30. Resource Recovery and Recycling; LAWMA: Ijora Olopa, Lagos, 2019.

31. Adeyemi, A.S.; Olorunfemi, J.F.; Adewoye, T.O. Waste scavenging in third world cities: A case study of Illorin, Nigeria. Environmentalist 2001, 21, 93-96. [CrossRef]

32. Oguntoyinbo, O.O. Informal waste management system in Nigeria and barriers to an inclusive modern waste management system: A review. Publ. Health 2012, 126, 441-447. [CrossRef] [PubMed]

33. Kaynak, R.; Toklu, A.T.; Elci, M.; Toklu, I.T. Effects of occupational health and safety practices on organizational commitment, work alienation, and job performance: Using the PLS-SEM approach. Int. J. Bus. Manag. 2016, 11, 146-166. [CrossRef]

34. Michael, J.H.; Evans, D.D.; Jansen, K.J.; Haight, J.M. Management commitment to safety as organizational support: Relationships with non-safety outcomes in wood manufacturing employees. J. Saf. Res. 2005, 36, 171-179. [CrossRef] [PubMed]

35. Rahiman, H.U.; Kodikal, R. Impact of employee work related attitudes on job performance. Br. J. Econ. Finance Manag. Sci. 2017, 13, 93-105.

36. Haque, M.F.; Haque, M.A.; Islam, M. Motivational theories-A critical analysis. ASA Univ. Rev. 2014, 8, 61-68.

37. Danish, R.Q.; Ramzan, S.; Ahmad, F. Effect of perceived organizational support and work environment on organizational commitment; mediating role of self-monitoring. Adv. Econ. Bus. 2013, 1, 312-317. [CrossRef]

38. Nigerian Economic Overview and Performance; World Bank: Washington, DC, USA, 2014. 